\title{
IPTEKS PROSES PENYUSUNAN ANGGARAN SEKTOR PUBLIK PADA BADAN PERENCANAAN PEMBANGUNAN, PENELITIAN DAN PENGEMBANGAN DAERAH (BAPELITBANGDA) KOTA MANADO
}

\author{
Fanda J. Mentang ${ }^{1}$, Nitha E. Makaminang ${ }^{2}$, David P.E. Saerang ${ }^{3}$ \\ 1,2,3 Jurusan Akuntansi, Fakultas Ekonomi dan Bisnis, Universitas Sam Ratulangi, J1. Kampus Bahu, Manado, \\ 95115, Indonesia \\ E-mail: mentangfanda@gmail.com
}

\begin{abstract}
The Development Planning Agency, Regional Research and Development of the City of Manado is a body that assists the Mayor in supporting government affairs in the fields of planning, research and development. In each program and activity requires funds, to see good financial use, a good budgeting process is needed that is in accordance with the guidelines in legislation which can reduce the risk of ineffective use of the budget. The purpose of the study was the Bapelitbangda of Manado city to provide information on how the government adhered to every regulation and policy regarding budgeting to create an accountability public sector organization. In accordance with Minister of Home Affairs Regulation No. 33 of 2017 concerning budgeting guidelines where Bapelitbangda is quite effective in implementing every rule and policy of regional government in terms of budgeting. Keywords: public sector budgeting process, Bapelitbangda Manado City
\end{abstract}

\section{PENDAHULUAN}

Pemerintah merupakan suatu lembaga organisasi publik yang di berikan kepercayaan dari masyarakat untuk mengolah keuangan suatu daerah. Informasi yang didapat atau yang diperoleh dari laporan keuangan pemerintah dapat membantu untuk mengambil berbagai keputusan dalam hal keuangan. Dilihat dari fungsi untuk memberikan informasi dimana digunakan sebagai alat untuk membandingkan setiap realisasi pendapatan serta pengeluaran atau belanja dengan anggaran yang sudah dianggarkan apakah sudah digunakan sesuai dan telah digunakan secara efektif serta efisien dalam penggunaan dana tersebut, tentunya dalam hal ini kita dapat menilai sejauh mana kinerja pemerintah dan seberapa taat mereka terhadap peraturan perundang-undangan yang telah ditetapkan sebelumnya.

Berdasarkan Musyudi (2009), Perencanaan keuangan yang baik dapat mencerminkan kinerja yang baik pada suatu instansi pemerintahan. Berbicara mengenai perencaanaan keuangan terdapat anggaran yang merupakan pertanggung jawaban mengenai penggunaan serta pengendalian terhadap program - program pembiayaan sosial, anggaran di gunakan untuk mengukur keberhasilan suatu program atau rencana pemerintah. Pada prakteknya kita sering menjumpai dimana anggaran disusun secara terpisah dengan rumusan serta perencanaan dan penerepan anggaran tidak sesuai dengan keberhasilan dan tujuan dari organisasi. Penyusunan anggaran dalam pemerintahan terkait dengan proses penentuan besar kecilnya dana yang digunakan untuk setiap program dan aktivitas yang berhubungan dengan keuangan. Proses penyusunan anggaran penting untuk mengetahui sejauh mana ke-efektifan dan ke-efisienan penggunaan anggaran dan dapat membantu melihat susunan perencanaan yang sudah berorientasi terhadap kinerja pemerintah.

\section{TINJAUAN PUSTAKA}

Proses penyusunan APBD. Menurut Wiratna Sujarweni (2015) Proses penyusunan APBD dilaksanakan oleh pemerintah dilihat dari kebutuhan dan kemampuan 
penyelenggaraan keuangan pemerintah yang disesuaikan dengan tingkat pendapatan daerah tersebut. Menurut Ayuningtyas Hertianti (2010) APBD disusun berdasarkan Rencana Kerja Pemerintah Daerah (RKPD) dengan tujuan untuk memberikan pelayanan yang sangat baik kepada masyarakat untuk menciptakan hubungan yang baik antara pemerintah dan masyarakat. Penyusunan APBD dimulai dari Kebijakan Umum APBD (KUA), Prioritas dan Plafon Anggaran Sementara (PPAS), Pedoman dalam menyusun Rencana Kerja Anggaran (RKA), Penyusunan rencana kerja oleh setiap SKPD serta penyiapan peraturan daerah dan tahap evaluasi.

Peraturan Menteri Dalam Negeri Republik Indonesia No. 33 Tahun 2017. Pedoman penyusunan Anggaran Pendapatan Dan Belanja Daerah Tahun anggaran 2018. Dalam pasal 1 ayat (1) menjelaskan, APBD merupakan rencana tahunan pemerintah mengenai keuangan yang ditetapkan dan disertai peraturan daerah serta kebijakannya. Ayat (2) mengatakan bahwa pedoman penyusunan APBD merupakan hal-hal pokok dimana terdapat kebijakan yang digunakan untuk mengarahkan Pemerintah Daerah dalam menyusun, membahas, bahkan menetapkan APBD. Pasal 2 ayat (1) mengenai pedoman penyusunan sebagai berikut, yaitu: sinkronisasi kebijakan pemerintah daerah dengan kebijakan pemerintah; prinsip penyusunan APBD, kebijakan penyusunan APBD, teknis penyusunan APBD; dan hal khusus lainnya.

\section{METODE DAN TEKNIK PENERAPAN IPTEKS}

\subsection{Metode Penerapan Ipteks}

Menerapkan metode ipteks yaitu prosedur penyusunan anggaran menurut PERMENDAGRI No. 33 Tahun 2017.

\subsection{Teknik Penerapan Ipteks}

Penggunaan teknik penerapan ipteks yaitu Permendagri No.33 Tahun 2017 sebagaimana dalam pasal 2 ayat (2) pedoman penyusunan APBD Tahun Anggaran 2018 mengenai unsur-unsur, yaitu sinkronisasi kebijakan pemerintah daerah dengan kebijakan pemerintah, prinsip penyusunan APBD, kebijakan penyusunan APBD, teknis penyusunan APBD.

\section{PEMBAHASAN}

\subsection{Gambaran Objek Penerapan Ipteks}

Berdasarkan website resmi Badan Perencanaan Pembangunan, Penelitian dan Pengembangan Daerah Kota Manado adalah badan yang di bentuk oleh Pemerintah berdasarkan Peraturan Pemerintah. Kemajuan perkembangan teknologi pada saat ini menjadikan teknologi sebagai kebutuhan dalam membantu proses pemerintahan dimana pemerintah daerah dapat melaksanakan perencanaan pembangunan serta program kegiatan pembangunan lainnya dengan lebih mudah. Kepala Badan selaku pemimpin yang dipercayakan oleh walikota Manado dimana setiap tugas dilaksanakan dibawah tanggungjawab walikota Manado. Berdasarkan undang- undang yang dibuat oleh pemerintah tentang Pemerintah Daerah telah memberikan keleluasaan serta wewenang bagi Pemerintah Daerah untuk dapat merencanakan segala program dan kebijakan sepenuhnya serta dapat menetapkan apa yang menjadi kebijakan dan program tersebut.

Bapelitbangda kota Manado mengemban tugas pokok dari pemerintah yaitu dalam hal membantu pemerintah kota Manado dalam pelaksaan setiap fungsi untuk menunjang urusan pemerintahan dalam hal perencanaan, penelitian dan pengembangan. Selain itu, terdapat beberapa fungsi dari bapelitbangda dimana dalam hal menyusun berbagai teknis kebijakan, melaksanakan tugas sesuai teknis, melakukan pemantauan terhadap program dan kegiatan serta melakukan evaluasi dan melaporkan setiap tugas yang sudah dilaksanakan, membina sesuai teknis dalam fungsi-fungsi penyelenggaraan urusan pemerintah, dan melaksanakan 
berbagai fungsi yang dipercayakan oleh walikota, semua fungsi tersebut dijalankan sesuai dengan setiap lingkup pekerjaan bahkan tugasnya.

\subsection{Pembahasan}

Proses Penyusunan Anggaran. Untuk menganalisis sistem penyusunan anggaran pada Bapelitbangda Kota Manado berdasarkan Abdul Hafiz (2009) Penatausahaan dan Akuntansi Keuangan Daerah untuk SKPD, dimulai dengan mengumpulkan data dari setiap SKPD yang terkait dengan program atau kegiatan pembangunan yang ada di Kota Manado yang sudah dilaksanakan ditahun anggaran tersebut. Kegiatan dan program yang dibuat oleh setiap bagian pada bidang - bidang yang di dasari pada strategi untuk perencanaan anggaran Bapelitbangda Kota Manado dimana memberikan arahan serta kebijakan dan strategi pembangunan mengenai anggaran pada tahun tersebut yang menjadi tolak ukur dalam menjalankan tugas dan fungsi dari Bapelitbangda Kota Manado dalam rangka membantu walikota. Sesuai dengan Permendagri No.33 Tahun 2017 yang menjadi acuan atau pedoman dalam proses penyusunan APBD terdapat 4 unsur yang menjadi pedoman penyusunan anggaran yakni mengenai:

1. Sinkronisasi Kebijakan Pemerintah Daerah Dengan Kebijakan Pemerintah. Bapelitbangda sebagai salah satu badan yang berfungsi untuk menunjang pemerintah dalam hal ini Walikota Manado, memliki fungsi untuk menyusun setiap kebijakan teknis. Dalam program perencanaan daerah sendiri sesuai analisis dari Andre Tulangow (2016), Bapelitbangda memiliki kebijakan bagaimana penyusunan rancangan RKPD dengan mengadakan penyelenggaraan Musrenbang RKPD. Selain itu, Bapelitbangda juga menyusun kebijakan umum APBD serta PPAS dan penyusunan kebijakan umum APBD perubahan dan PPAS perubahan. Jadi, sinkronisasi kebijakan Pemerintah Daerah dan Pemerintah dalam hal ini Bapelitbangda kota Manado selanjutnya dibuat dalam suatu rancangan mengenai kebijkan umum dan penggunaan anggaran atau KUA PPAS.

2. Prinsip Penyusunan APBD. Berdasarkan Wawancara dengan Ibu Maria Runtuwene, Bapelitbangda dalam proses penyusunan rencana anggaran mempunyai prinsip dalam melaksanakan tugas bahkan fungsi untuk dapat berhasil mewujudkan apa yang menjadi tujuan dan rencana yang dibuat. Perencanaan keuangan yang disusun harus berdasar, dimana struktur organisasi pemerintah harus ada ketegasan dan tanggung jawab terhadap suatu pekerjaan yang akan di laksanakan walaupun mereka dapat memberikan wewenang atau melimpahkan kuasa kepada bawahannya.

3. Kebijakan Penyusunan APBD. Dokumen KUA PPAS dibuat oleh Sekretaris Daerah mengenai anggaran untuk disampaikan kepada pemerintah dimana dokumen ini menjadi penunjuk dalam proses menyusun APBD berdasarkan rencana kerja yang di peroleh dari Musrenbang, kemudian diberitahukan selambat - lambatnya pada bulan juni di minggu yang pertama. Dalam Kebijakan penyusunan APBD terdapat keadaan perekonomian daerah, serta kebijakan-kebijakan mengenai pendapatan, belanja serta berbagai pembiayaan. Dalam hal ini Bapelitbangda Kota Manado juga menetapkan apa yang menjadi prioritas untuk pembangunan serta program yang membutuhkan dana.

4. Teknis Penyusunan Anggaran. Menurut Sony Yuwono (2005), Penyusunan anggaran merupakan suatu hal yang sangat penting dalam mengetahui apakah anggaran sudah digunakan dengan baik oleh suatu lembaga untuk menilai ke-efektifan penggunaan dana tersebut untuk program atau kegiatan pemerintah. Ada juga Teknik Penyusunan Anggaran berdasarkan kesimpulan Rinni Rorong (2017), digunakan oleh Pemerintah Kota Manado termasuk Bapelitbangda, dimulai dengan penyusunan dari Rencana Pembangunan Jangka Panjang Daerah (RPJPD) sesuai dengan kebijakan walikota Manado dengan tidak lupa memperhatikan Rencana Pembangunan Jangka Menengah Nasional (RPJMN). RPJPD adalah dokemen perencaanaan daerah yang dibuat untuk periode dua puluh tahun (20 tahun), dokumen ini menjadi referensi atau acuan bagi 
Pemerintah untuk Rencana Pembangunan Jangka Menengah Daerah (RPJMD) untuk periode lima tahun. Kemudian menyusun rencana kerja dari pemerintah, selanjutnya menyusun rancangan mengenai kebijakan penggunaan APBD yang akan disepakati menjadi Kebijakan Umum Anggaran setelah itu membuat hal-hal yang menjadi prioritas dari penggunaan anggaran yang biasa dikenal dengan PPAS yang merupakan tugas dari kepala daerah untuk disepakati bersama sesuai dengan analisis Riska Korompot (2015). Selanjutnya mereka menetapkan hal-hal mengenai penyusunan Rencana Kerja dan Anggaran (RKA) SKPD sebagai pedoman kepala SKPD menyusun RKA-SKPD berdasakan hasil akhir. Selanjutnya menyusun rencana peraturan daerah oleh walikota Manado tentang penjabaran APBD. Jadi setiap kebijakan dan teknis penyusunan anggaran yang ada di Bapelitbangda Kota Manado merupakan salah satu tugas dan fungsi dari Walikota Manado kepada Bapelitbangda Kota Manado dalam rangka program perencanaan daerah kota Manado.

\section{KESIMPULAN DAN SARAN}

\subsection{Kesimpulan}

Anggaran yang disusun BAPELITBANGDA Kota Manado akan efektif dan berjalan dengan baik apabila berpedoman pada peraturan pemerintah dan menjalankan setiap unsur yang terdapat dalam pedoman penyusunan anggaran yang sudah di tetapkan untuk menjadi dasar ketaatan pemerintah terhadap unsur-unsur tersebut.

\subsection{Saran}

Perlunya pengetahuan dan penerepan yang baik mengenai setiap peraturan pemerintah yang dituangkan dalam perundang-undangan agar dapat terbentuknya pemerintahan yang baik dalam hal penyusunan anggaran untuk dapat mewujudkan setiap program dan kegiatan sesuai dengan kebijakan pemerintah daerah.

\section{DAFTAR PUSTAKA}

Bapelitbangda Kota Manado. Profil Lembaga Pemerintah. http://bapelitbangda.manadokota.go.id/

Hafiz, Abdul. 2009. Penatausahaan dan Akuntansi Keuangan Daerah Untuk SKPD. Buku 1 Edisi 2. Jakarta

Hertianti, Ayuningtyas. 2010. Akuntansi Sektor Publik. Jakarta

Korompot, Riska, dan Poputra, A.T. 2015. Analisis Penyusunan Anggaran Pada Dinas Pendapatan Pengelolaan Keuangan dan Aset Daerah Kota Kotamobagu Tahun Anggaran 2014. Jurnal Riset Ekonomi, Manajemen, Bisnis dan Akuntansi, 3(1), 841848.

Musyudi. 2009. Akuntansi Pemerintahan di Indonesia. PT Refika Aditama, Bandung

Peraturan Menteri Dalam Negeri No.33 Tahun 2017 Tentang Pedoman Penyusunan Anggaran

Peraturan Pemerintah RI No. 71 Tahun 2010. Tentang Standar Akuntansi Pemerintah

Rorong, Rinni, Kalangi, Lintje, dan Affandi, Dhullo. 2017. Analisis Sistem Penyusunan Anggaran Pemerintah Kota Manado (Studi Kasus Pada Sekretariat DPRD Kota Manado). Jurnal Riset Ekonomi, Manajemen, Bisnis dan Akuntansi, 5(2), 2331-2340.

Runtuwene, Maria wawancara. 2018. Wawancara mengenai Proses Penyusunan Anggaran. Jl. Balai Kota,

Sujarweni, Wiratna. 2015. Akuntansi Sektor Publik. Penerbit Pustaka Baru Press, Yogyakarta 
Tulangow, Andre, dan Runtu, Treesje. 2016. Analisis Realisasi Anggaran Pendapatan Dan Belanja Daerah Kabupaten Minahasa. Jurnal Riset Ekonomi, Manajemen, Bisnis dan Akuntansi, 4(3), 564-571.

Yuwono, Sony. 2005. Penganggaran Sektor Publik. Terbitan Bayu Media, Malang. 